\title{
POWERS OF LIFE AND DEATH: ASPECTS OF MATERNAL WELFARE IN ENGLAND AND WALES BETWEEN THE WARS
}

by

ENID FOX *

A long series of official reports testifies to the importance of maternal mortality as a social problem for most of the inter-war period. ${ }^{1}$ A number of historians have studied its significance, with some reference to the "medicalization" of childbirth: most exhaustively, Jane Lewis, in connection with the politics of maternity care, and Irvine Loudon, in his reconsiderations of causality. ${ }^{2}$ The first part of this paper deals with the dimensions of this social problem, reviews explanations of the maternal mortality rates and the general lines of debates surrounding them, and identifies different views about the quality of maternity services and their relationship to maternal mortality.

The second part explains what services were available, paying special attention to home confinements and attendance on them by midwives and general practitioners; it takes up the details of arguments advanced about their work and reviews the development of relevant policy in the late 1930s. The paper argues that the credit due to scientific and public health medicine for improving women's chances of life can be greatly offset by evidence that medical power was exerted in ways which favoured professional interests when they came into conflict with clients' welfare.

* Enid Fox, B.Sc.(Soc.), Principal Lecturer in Social Policy, School of Health and Human Sciences, Hatfield Polytechnic, College Lane, Hatfield, Herts., AL10 9AB.

Abbreviations used are, NBT: National Birthday Trust; PRO: Public Records Office; QI: variously Queen Victoria's Jubilee Institute for Nurses, Queen's Institute of District Nursing, and the Queen's Nursing Institute; RCOG: Royal College of Obstetricians and Gynaecologists.

\footnotetext{
1 Janet Campbell, Maternal Mortality and The Protection of Motherhood, Reports on Public Health and Medical Subjects, nos. 25 and 48, London, HMSO, 1924 and 1927; Ministry of Health, Interim Report and Final Report of the Departmental Committee on Maternal Mortality and Morbidity, London, 1930 and 1932; Ministry of Health, Report on an Investigation into Maternal Mortality and Maternal Mortality in Wales, Cmd 5422 and 5423, London, HMSO, 1937.

2 Jane Lewis, The politics of motherhood, London, Croom Helm, 1980, pt. 3; Ann Oakley, The captured womb, Oxford, Blackwell, 1984, pp. 12-17 and 275-7; (on medicalization) Colin Jones, 'Montpellier medical students and the medicalisation of eighteenth century France', in Roy Porter and Andrew Wear (eds.), Problems and methods in the history of medicine, London, Croom Helm, 1987, pp. 57-8; Irvine Loudon, 'Obstetric care, social class and maternal mortality', Br. med. J., 1986, 293: 606-8; 'Deaths in childbed from the eighteenth century to 1935', Med. Hist., 1986, 30: 1-41; 'Puerperal fever, the streptococcus and the sulphonamides 1911-1945', Br. med. J., 1987, 295: 485-90; 'Maternal mortality: 1880-1950. Some regional and international comparisons', Soc. Hist. Med., 1988, 1(2): 183-228; Alison Macfarlane and Tim Cole, 'From depression to recession', in Maternity Alliance, Born unequal, London, Maternity Alliance, 1985, pp. 40-2.
} 


\section{Maternal welfare in England and Wales}

MATERNAL MORTALITY AS A SOCIAL PROBLEM

Maternal mortality means deaths due to pregnancy and childbirth. ${ }^{3}$ Its rates for England and Wales, expressed as numbers of deaths per 1,000 births, were 4.9 for 1851-1855 (the first five-year period for which civil registration permitted a reasonably reliable calculation) and 4.3 for 1931-1935, after which there was a sustained decline. Despite year-to-year fluctuations and changes in definitions, classifications, and the registration system's capacity for full recording, the rates were usually taken to mean that the risks of childbirth were fairly constant despite general improvements in the national health and supposedly beneficial changes in obstetric practices and maternity services. Dissenting from this conventional wisdom, Edward Shorter has claimed that antiseptic and aseptic techniques in use from the 1880s brought about reductions in the number of deaths from puerperal sepsis (the biggest single cause) that were obscured by increasing incidences of deaths not ascribed to the abortions that caused them; but Loudon's analysis supports convention. ${ }^{4}$ Contemporary observers' reservations about the influence of abortion on the maternal mortality rates were less to do with the deaths it brought about than with the changing, but incalculable relationship between the total numbers of pregnancies and of those taken to full term. Dr Andrew Topping, whose period of office as Medical Officer of Health for Rochdale from 1930 to 1932 marked a decline in the borough's maternal mortality rates from an annual average of just under 9 for 1928-1931 to 3 for 1932-1935, drew attention to the unsoundness of using the number of live births as a base for indicators of the risks of deaths from pregnancy and childbirth. ${ }^{5}$ But no matter how misleading the average, annual rates might have been, it was generally agreed that the numbers of deaths were well above the irreducible minimum; and the national averages concealed wide variations between different localities, which remained fairly steady from place to place and have never satisfactorily been explained. ${ }^{6}$

The first person to recognize and state repeatedly that not only was the level of maternal mortality in England and Wales too high, but that many puerperal deaths were avoidable, was William Farr in his appendices to the Annual Reports of the Registrar General in the 1870s, but it was not until 1924 that the new Ministry of Health began systematically to address them. Reports in 1924 and 1927 by Dr Janet Campbell, its Medical Officer in charge of maternal and child welfare, led to complementary Departmental Committees, one on midwifery which reported in 1929 , and the other on maternal mortality, reporting in 1930 and $1932 .^{7}$ None of the Committees' reports resulted in new policy.

\footnotetext{
${ }^{3}$ The more precise term is "puerperal mortality", but "maternal mortality" was customary usage, as here defined.

${ }^{4}$ Edward Shorter, A history of women's bodies, Harmondsworth, Penguin, 1984 (first publ. New York, Basic Books, 1982), p. 131; Loudon, 'Deaths in childbed', note 2 above, pp. 25-7.

${ }^{5}$ Andrew Topping, 'Maternal mortality and public opinion', Publ. Hlth, July 1936, 49: 342-9.

${ }^{6}$ See Macfarlane and Cole, op. cit., note 2 above, and Loudon, 'Obstetric care' and 'Maternal mortality', note 2 above, for recent reviews.

${ }^{7}$ Campbell, Maternal Mortality and Protection of Motherhood, note 1 above; Ministry of Health, Report on the Training and Employment of Midwives, London, HMSO, 1929; Ministry of Health, Interim and Final Reports on maternal mortality, note 1 above.
} 
This was not for want of recommendations. The Midwives Committee, set up because midwifery lacked recruits, sought to raise the status of a profession dependent on poor women's fees through a complicated plan for subsidizing independent midwifery out of National Insurance funds. ${ }^{8}$ The Maternal Mortality Committee, chaired by Sir George Newman, the Ministry's Chief Medical Officer, called for a National Maternity Service with midwives or maternity nurses for every case, doctors for examinations and attendances as required, consultants available on doctors' referrals, hospital beds as necessary, and adequate ancillary services such as transport, sterilized equipment, and laboratories. ${ }^{9}$ The two sets of proposals were predictable in principle if not in detail; the Maternal Mortality Committee's analyses of the causes of maternal deaths provided a powerful case for strengthening the health services centred upon local authorities, to which Newman was committed. They entailed mobilizing private and voluntary resources of health care; a sufficient supply of independent midwives to provide attendance within the means of poor women was crucial.

The Committees' ambitions foundered in an economic crisis, when "straitened circumstances" made it impossible for the Ministry to encourage or approve increased expenditure except in "very black areas". ${ }^{10}$ Further investigations into maternal mortality in places with especially high rates were put in hand as tokens of continuing concern; reports of their findings in 1937 coincided with the beginning of a substained decline in the national rates. Within a decade, maternal mortality lost its status as a social problem.

Its rehabilitation as an historical problem has been partly a matter of reconsidering questions of causality left unresolved with the rates' decline, and partly one of reviewing questions opened up by the Departmental Committees.

\section{EXPLANATIONS AND PRESCRIPTIONS}

The Maternal Mortality Committee collected data on 5,805 maternal deaths between November 1928 and July 1932, but considered the findings of its Interim Report, 1930, to be representative. They were based on the first 2,000 deaths; 404 were due to causes other than childbearing and the reports on 310 others were discarded as inadequate or not strictly relevant to the enquiry. Of the remaining 1,286 cases, 626 were ascribed to "primary avoidable causes", in the following proportions: "faulty antenatal care", 36.2 per cent; "error of judgement", 35.7 per cent; "lack of reasonable facilities", 10.2 per cent; and "negligence of patient or her friends", 17.9 per cent. The statistical categories are very broad and the allocation of cases to them is open to question, but the findings were presented as likely to have understated the extent of avoidable death because of the numbers of cases excluded for lack of information: it looked as though the mortality rates could be halved. Official

\footnotetext{
${ }^{8}$ Ministry of Health, Report on midwives, note 7 above, summary of conclusions and recommendations, p. 69.

${ }_{9}^{9}$ Ministry of Health, Interim Report on maternal mortality, note 1 above, para. 207.

10 PRO, MH55/246, W. A. Robinson to Sir R. Bolam (Chairman, Midwives Committee) on the financial standstill, 27 June 1930; MH55/273, Sir G. Newman after the publication of the Maternal Mortality Committee's Final Report.
} 


\section{Maternal welfare in England and Wales}

reservations about the dangers of over-simplistic interpretations were not expressed until completion of the subsequent special investigations; the reports on them, in 1937, drew attention to the small, absolute number of deaths and warned against the vulgar error of expecting an easy progression from avoidability to avoidance, something for which both Topping and Sir Henry Brackenbury, arguing the case for a standardized system of maternity care, had already criticized the Committee. ${ }^{11}$

Despite the general agreement about the need for improved services there was dispute about their organization and control. In 1929, and again in 1935 when there were further moves towards reform, the British Medical Association presented plans for maternity services centred on general practitioners rather than on local authorities' health departments. ${ }^{12}$ More immediately and politically sensitive was the criticism of the official inquiries' concentration on clinical causes rather than on socio-economic factors, notably malnutrition, likely to bear on women's chances of surviving childbirth. Brackenbury's paper represented this line of argument, but it was most strongly taken up by the unofficial Maternal Mortality Committee which shadowed its Departmental counterpart. ${ }^{13}$ Fortuitously, the mortality rates declined, and controversy with them.

Sulphonamide drugs came into use in the late 1930s and reduced the level of puerperal fever that was the main, single cause of maternal deaths, although their introduction was not so well synchronized with the drop in the maternal mortality rates as indisputably to account for it. The incidence of maternal deaths from other causes also fell. In 1949, Sir William Gilliatt reviewed the decline alongside an analysis of maternal deaths in 1947 in order to identify the residue of deaths from specific, avoidable causes and to clarify the means of reducing maternal mortality even further. ${ }^{14} \mathrm{He}$ credited chemotherapy for the breakthrough, with penicillin following the sulphonamides from the last year of the war. The category of puerperal sepsis included septic abortion, which was not susceptible to sulphonamides, and Loudon has now shown that the two components' different patterns of decline related to the introduction of the different drugs. ${ }^{15}$

Two other aspects of puerperal sepsis were considered; the virulence of the streptococcus and standards of asepsis and antisepsis. Gilliatt and others thought there had been a decline in virulence from the mid-1930s but an earlier inquiry by Drs Colebrook and Kenny had already confirmed the effectiveness of sulphonamides; and

\footnotetext{
${ }^{11}$ Ministry of Health, Report on an Investigation, note 1 above, p. 187: "easy to be wise after the event"; Lewis, op. cit., note 2 above, p. 40; Topping, op. cit., note 5 above, p. 343; Sir Henry Brackenbury, 'Maternity in its sociological aspects', Soc. Service Rev., March 1937, pp. 37-47. Brackenbury was Chairman of the Council of the BMA.

12 British Medical Association, 'Memorandum regarding national maternity service', Br. med. J. Suppl., 1935, ii: 295-8; a similarly titled pamphlet was published in 1929: see Frank Honigsbaum, Health, happiness and security: the creation of the National Health Service, London, Routledge, 1989, pp. 6-7.

${ }^{13}$ Lewis, op. cit., note 2 above, pp. 39-40. Brackenbury (op. cit., note 11 above) did not take the socio-economic argument to the conclusion of prescribing economic aid.

${ }^{14}$ Sir William Gilliatt, 'Maternal mortality', in Alec W. Bourne and W. C. W. Nixon (eds.), Transactions of XIIth British Congress of Obstetrics and Gynaecology, London, Austral Press, 1949, pp. 269-303.

${ }^{15}$ Loudon, 'Maternal mortality', note 2 above, pp. 196-206.
} 


\section{Enid Fox}

Loudon considers that streptococcal change is unlikely to have been of consequence, at least in the early years of falling maternal mortality rates. ${ }^{16}$

No less an authority than William Blair Bell, former Professor of Midwifery and Gynaecology at Liverpool University and first President of the College of Obstetricians and Gynaecologists, asserted in 1931 that midwives without nursing qualifications were insufficiently aware of the need for surgical cleanliness; ${ }^{17}$ and an investigation in 1923 found that sterilization techniques taught to pupil midwives were "hit and miss" and that midwives rarely used surgical gloves. ${ }^{18}$ But their use by doctors was even rarer, and a common belief that obstetrics did not require the same standards as general surgery is said to have been reflected in some teaching hospitals' techniques as late as the 1930 s. ${ }^{19}$ If this were so, any shortcomings were not limited to midwives. One explanation for midwives' cases having lower incidences of puerperal fever than those of doctors has been that midwives specialized and so were not at risk of transmitting the infections to which doctors were exposed in their daily work ${ }^{20}$ But the women whose work was analysed by the eminent obstetrician John Shields Fairbairn in 1927, and commended for their good record on maternal mortality, were mostly village nurse-midwives who combined midwifery with general nursing and were unlikely to have nursing qualifications or hospital training. ${ }^{21}$

Deaths from causes other than sepsis declined from the late 1930 s, less dramatically than did the general rates, as table 1 shows.

Table 1: Maternal mortality rates (including abortion deaths) per 1,000 live births, 1920-1942.

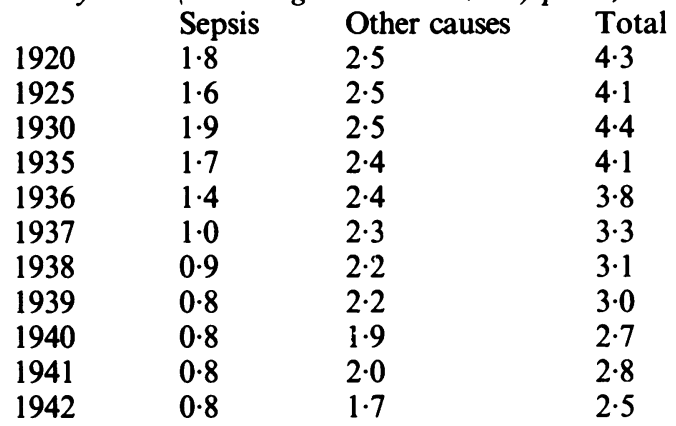

(Source: Royal College of Obstetricians and Gynaecologists, Report on a national maternity service, London, RCOG, 1944: extracted from Fig. 1, p. 4.)

\footnotetext{
16 Gilliatt, op. cit., note 14 above, p. 270; Leonard Colebrook and Meave Kenny, 'Treatment with Prontosil of puerperal infections', Lancet, 1936, ii: 1319-22; Loudon, 'Maternal mortality', note 2 above, pp. 199-200. Alison Macfarlane and Miranda Mugford, Birth counts, London, HMSO, 1984, p. 206: on the difficulty of dissociating an apparently earlier start to the falling trend from an insignificant downward fluctuation that immediately preceded a fall due to sulphonamides, citing C. A. Douglas and P. L. McKinley, Report of Maternal Mortality in Scotland, Edinburgh, Dept. of Health for Scotland, 1935, and J. Webb and P. Webster-Edwards, 'Recent trends in maternal mortality', Medical Officer, 1951, 86: $201-4$.

17 W. Blair Bell, 'Maternal disablement', Lancet, 1931, i: 1279-86.

18 Joan Towler and Jean Bramall, Midwives in history and society, London, Croom Helm, 1986, p. 205.

19 Loudon, 'Puerperal fever', note 2 above, p. 487 (regarding teaching hospitals).

20 Ibid.; Loudon, 'Maternal mortality', note 2 above, p. 209.

21 John S. Fairbairn, 'Observations on the maternal mortality in the midwifery service of the Queen Victoria's Jubilee Institute', Br. med. J., 1927, i: 47-50. (The QI's name has changed twice since its inception in 1887.)
} 


\section{Maternal welfare in England and Wales}

Blood transfusion, from the early years of the war, was the only clinical intervention specifically identified in connection with deaths from causes other than sepsis, but informed opinion suggested that it had not reached its maximum effect by the 1950 s. $^{22}$ Gilliatt's study included a detailed account of the standard procedures for preventing and replacing loss of blood, implying that even by 1949 they were not always followed. ${ }^{23}$

Loudon allows malnutrition some small role in deaths from haemorrhage, which Gilliatt thought likely to have been the unrecorded but direct cause of some deaths attributed to other "accidents of childbirth" in 1947. ${ }^{24}$ Toxaemia was down by 55.5 per cent since 1927 but Gilliatt judged it capable of further reduction as the antenatal monitoring and dietary control that accounted for the improvement were not yet universally practised. ${ }^{25}$ This was his only explicit reference to diet as a causal factor, although it is implied in his opinion that the psychiatric conditions said to cause some deaths in the puerperium could be tempered by good physical health, and he said that improved wartime diet had contributed to the sustained, general decline in maternal mortality. 26

Those who complained of the lack of official attention to malnutrition were ill-served by an experiment carried out in Glamorgan by the National Birthday Trust. ${ }^{27}$ It claimed to have achieved dramatic reductions in maternal mortality by supplementing pregnant women's diets, but it suffered from a notable disregard of experimental control. An oral account given in the project's early days by Lady Williams, of the NBT, suggested that its management was so confused as to cast doubt on its findings, even had its methods been less questionable; Dr Letitia Fairfield, a Senior Medical Officer with the London County Council, said the results were too good to be true. ${ }^{28}$ It was easy for the Ministry of Health to dismiss them.

Madeleine Mayhew's exposition of the Ministry's robust resistance to scientific evidence on nutritional needs or, at least, to its implications for "wages, cost of food, doles, etc." makes no judgement on the validity of Lady Williams's work, which has been uncritically accepted by other recent writers. ${ }^{29}$ Loudon is an exception, but his reference to concurrent but unspecified improvements in the Rhondda's maternity services is not enough to explain the declining rates that Lady Williams reported. ${ }^{30}$

${ }^{22}$ Loudon, 'Maternal mortality', note 2 above, pp. 196, 202, 223.

${ }^{23}$ Gilliatt, op. cit., note 14 above, p. 272.

${ }^{24}$ Loudon, 'Maternal mortality', note 2 above, pp. 197-8; Gilliatt, op. cit., note 14 above, p. 271.

${ }^{25}$ Ibid., pp. 270-1.

26 Ibid., pp. 270, 277.

${ }^{27}$ PRO MH55/649, report in The People, 22 May 1938, forecasting the official provision of special food for expectant mothers. Lady Rhys Williams, 'Malnutrition as a cause of maternal mortality', Publ. Hlth, October 1936, 50: 11-19, and 'Results of an experimental scheme for reducing the maternal death rate', ibid., April 1937, pp. 231-3. The NBT was a voluntary agency established in 1928.

${ }_{28}$ PRO PRO30/63/559, QI's papers on Glamorgan County Nursing Association: meeting of a joint committee of the QI and the NBT, 2 March 1934. The QI's promotion of district nursing in Glamorgan was thought to be jeopardized by the NBT's project, which included maternity nursing. See Lewis, op. cit., note 2 above, pp. 181-2, on Dr Fairfield.

${ }^{29}$ Madeleine Mayhew, 'The 1930s nutrition controversy', J. contemp. Hist., July 1988, 23(3): 445-63: see especially pp. 451, 455; Charles Webster, 'Healthy or hungry thirties', Hist. Workshop J., 1982, 13: 120-1; Margaret Mitchell, 'The effects of unemployment on the social conditions of women and children', ibid., 1985,19, p. 115. But see also Richard M. Titmuss, Poverty and population, London, Macmillan, 1938, ch. 7.

${ }^{30}$ Loudon, 'Deaths in childbed', note 2 above, p. 36. 
The modest claims of a later experiment by the People's League of Health were favourably received by the Ministry, even though the League had failed to get official backing for the research in 1936, when the tide in the Ministry's attitude to nutrition was just about on the turn. ${ }^{31}$ Dr Carnwath, Sir George Newman's deputy, was strongly critical although he acknowledged the "distinguished auspices" of the research project's steering committee of forty-five members, including Sir John Boyd Orr, whose research had formed the major part of the nutritionists' case against the Ministry. ${ }^{32}$ The League's interim report was enthusiastically accepted in 1942; by then, extra food for expectant mothers was wartime policy. ${ }^{33}$

Loudon has concluded, with emphasis, "that maternal mortality appears to have been remarkably resistant to the ill-effects of social and economic deprivation, but remarkably sensitive to the good and the bad effects of medical intervention". 34 The second half of his statement is borne out by the evidence of chemotherapy's beneficial effects and of other interventions' ill effects, adduced later in this paper. The case that poverty and malnutrition had little to do with maternal mortality before 1937 is not made, however; the matter was never specifically investigated. Whatever the shortcomings of Lady Williams's research, it justified further inquiries; both Gilliatt and Loudon credit wartime nutrition with helping to sustain maternal mortality's decline.

They are not in accord about the debatable relationship between maternal mortality and maternity services. During the 1930 s the number of antenatal clinics rose from 1,000 to at least 1,500 , the proportion of institutional confinements increased to over 35 per cent of births, and local authorities introduced schemes for paying general practitioners for antenatal examinations. ${ }^{35}$ These changes imply an enlarged scope for precautionary admission to hospital for women at special risk. But doubts had been expressed about general practitioners' capacity for antenatal care; the reports of the special investigations in 1937 stressed the extent to which the effectiveness of antenatal services depended on women's willingness to use them and Topping's work at Rochdale suggested that they needed the support of sustained educational campaigns. ${ }^{36}$ And, according to Loudon, the improvement of midwives' practice after its statutory control in 1902 was disappointingly slow, with standards still so poor before the Second World War as to have affected maternal mortality. ${ }^{37}$

\footnotetext{
${ }^{31}$ People's League of Health, interim report 'Nutrition of expectant and nursing mothers', Lancet, 4 July 1942, pp. 10-12. See Greta Jones, Social hygiene in twentieth century Britain, London, Routledge, 1986, on the PLH.

32 PRO MH55/649: Dr T. Carnwath to Sir G. Chrystal, 10 August 1936, on the League's deputation to the Ministry, 21 July 1936; see Mayhew, op. cit., note 29 above, for official attitudes to nutrition.

${ }^{33}$ PRO MH55/649: an interim report recommended as "excellent" by Drs Magee and Taylor to the Chief Medical Officer, 20 and 22 May 1942.

${ }^{34}$ Loudon, 'Deaths in childbed', note 2 above, p. 27.

35 RCOG, Report on a national maternity service, pp. 25, 28; but the Ministry of Health's rough estimate of clinics in 1937 was 1,600, see PRO MH55/682: A. J. MacLachlan's notes of 7 June and 27 July 1937, on the BMA's plans. Examples of local arrangements for paying GPs are in various County Nursing Association files, PRO PRO30/63.

${ }^{36}$ Honigsbaum, op. cit., note 12 above, p. 6; Ministry of Health, Reports on maternal mortality, note 1 above; Topping, op. cit., note 5 above, pp. 344-5.

${ }^{37}$ Loudon, 'Deaths in childbed', note 2 above, p. 39.
} 


\section{Maternal welfare in England and Wales}

The extension of midwives' training at the end of the 1930s and the continuing trend towards institutional confinements, accounting for more than 50 per cent of births by the mid-1940s, supports Loudon's attribution of some of the credit for the continuing postwar decline in maternal mortality to improvements in services, especially during the war. ${ }^{38}$

His criticism of prewar midwives is doubtfully grounded, relying partly on the assumption that trained midwifery meant better practice, an improvement that was constrained by the rate of decline of the licensed, but untrained midwife - the "bona fide" midwife discussed at more length in the second part of this paper-and he has interpreted Topping's experience as conclusive evidence of poor standards in the 1930 s. $^{39}$ In fact, Topping reported midwives' average standard to be good, and improving. He identified shortcomings in all the occupational groups involved with maternity care, including midwives, and although his criticism of consultants made special mention of those who did not speak out about the bad midwifery that they talked about in private, his reference seems, in context, to have been wholly or largely to general practitioners' midwifery. ${ }^{40}$ There was no correlational decline in the maternal mortality rates as the untrained midwives died out, and neither they nor trained midwives were especially implicated in the findings of the various inquiries into maternal deaths.

Loudon has cited the papers of the formal discussion which followed Gilliatt's address to the British Congress of Obstetricians and Gynaecologists, 1949, in support of his list of factors contributing to the continuing fall in maternal mortality rates into and through the 1940s, but they do not bear out his inclusion, among those factors, of "better education of medical students... [and] greater cooperation between general practitioners and midwives and consultants ...". 41 The Congress was opened by Aneurin Bevan, Minister of Health, and some of those present took strong and concerted exception to his attribution of the continuing reduction in maternal death-rates "to teamwork in the maternity services of Great Britain". 42 It was a provocative remark for Bevan to make the day after the National Health Service's first birthday, as its arrangements for maternity care represented his eleventh-hour retreat from plans for restricting general practitioners' midwifery to doctors with relevant postgraduate training or experience, which the obstetricians had long advocated. ${ }^{43}$ Nevertheless, the indignation which surfaced when Gilliatt's research was discussed does not invalidate his plea for domestic midwifery to be reinforced by practitioners with six months' residential experience, nor his fellow consultants' judgement that the quality of maternity care was in jeopardy.

Although the maternal mortality rates fell by 61 per cent over the twenty years to 1947 , the rates for "accidents of childbirth" fell by only 24.6 per cent. Gilliatt spoke of

\footnotetext{
38 Towler and Bramall, op. cit., note 18 above, p. 238; Joint Committee of RCOG and Population Investigation Committee, Maternity in Great Britain, London, Oxford University Press, 1948, pp. 48-9, 54; Loudon, 'Deaths in childbed', note 2 above, p. 41.

39 Ibid., p. 39.

40 Topping, op. cit., note 5 above, pp. 347-8.

${ }^{41}$ Loudon, 'Deaths in childbed', note 2 above, p. 41.

42 Bourne and Nixon, op. cit., note 14 above, pp. 14-15; Gilliatt, op. cit., note 14 above, pp. $283-303$.

${ }^{43}$ Frank Honigsbaum, The division in British medicine, London, Kogan Page, 1979, p. 155.
} 


\section{Enid Fox}

general practitioners' ill-judged and unskilled interventions: "every year many mothers and many more babies pay with their lives...". It was argued in the discussion that codified regimes of antenatal care-knowledge of which had undoubtedly advanced over the previous twenty years - could be counterproductive if not in experienced hands; that midwives' training was now far better than that of the average newly-qualified doctor; and that the National Health Service's financial arrangements not only induced inexperienced general practitioners to take as many maternity patients as possible, but they gave local authorities incentives to encourage women to book doctors rather than midwives for home confinements. ${ }^{44}$

If such a debate could take place as late as 1949 and be adduced by a modern historian as evidence of services by then so superior as to have reduced women's risks of dying in childbirth, what were the services like when maternal mortality was a recognized social problem? The second part of this paper considers confinement arrangements, professional attendance on home births, and the reform of midwifery services at the end of the 1930s.

\section{CONFINEMENT ARRANGEMENTS AND COSTS}

Assuming that unattended births were rare and that there was general compliance with the law prohibiting unlicensed attendance, childbirth was attended by consultant or specialist obstetricians, general practitioners, or midwives. ${ }^{45}$ After 1918 , local authorities could make institutional provision and small maternity homes attended by local doctors were favoured. For England and Wales in 1936, nearly 35 per cent of live births were recorded as occurring in institutions as against 24 per cent in 1932 and 15 per cent in $1927 . .^{46}$ It was estimated in 1930 that midwives attended about 60 per cent of the "some 650,000 women [who] undergo the task and privilege of childbirth" every year, and the evidence of private midwives' fees supports the impression that their clientele was generally poor. ${ }^{47}$ The district nursing associations which provided midwifery in connection with the Queen's Institute of District Nursing, the voluntary agency co-ordinating most of the district nursing in England and Wales, charged for midwifery at rates on a par with those of independent midwives. ${ }^{48}$ The associations served poor people and there had never been any question of patients paying market rates for general nursing. The long-standing rule on midwifery charges suggests that private midwifery was considered to be within a poor woman's means.

${ }^{44}$ Gilliatt, op. cit., note 14 above, pp. 276, 283-303, especially Prof. Hilda Lloyd, G. W. Theobald, and W. R. McLennon in discussion.

${ }^{45}$ Towler and Bramall, op. cit., note 18 above, p. 209. The Midwives Act of 1926 limited unqualified midwifery to cases of "sudden and urgent necessity" in an attempt to discourage evasions of earlier legislation on the pretext of "emergency".

${ }_{46}$ Arnold L. Walker, 'Midwife services', in J. M. Munro Kerr, R. W. Johnstone, and Miles H. Phillips (eds.), Historical review of British obstetrics and gynaecology, 1800-1950, Edinburgh and London, Livingstone, 1954, p. 340, citing the Registrar General's statistical review for England and Wales, 1937.

47 Ministry of Health, Interim Report, note 1 above, para. 197; PRO MH55/270, a draft interim report that concluded that 60 per cent of home confinements were attended by midwives; MH55/652, an undated precis (1935?) of a report of the Joint Committee on Midwives, also estimated 60 per cent; MH55/240: Midwives Institute's estimates of midwives' expected earnings based on $£ 1.5 s$. per case. See the Report on midwives, note 7 above, paras. 52, 59; Lewis, op. cit., note 2 above, p. 141, has other examples of fees.

${ }^{48}$ PRO MH55/239: district nursing associations' midwifery fees matched private midwives' and were from $£ 1$ to $£ 2.2 s$. per case: written evidence from QI to Midwives Committee. 


\section{Maternal welfare in England and Wales}

The place of birth is no guide to the status of the birth attendant. Midwives worked in all types of maternity homes and hospitals. ${ }^{49} \mathrm{~A}$ home confinement did not necessarily mean delivery by the doctor or midwife booked for it. Delivery in a "doctor's case" might be by his maternity nurse, and a doctor might take over a "midwife's case" presenting complications. A maternity nurse with no midwifery qualification risked a $£ 10$ fine for undertaking a delivery except when there was "sudden and urgent necessity", but midwives, including those employed by district nursing associations, might act as maternity nurses. ${ }^{50}$ The rules of the Central Midwives Board required midwives to call doctors in cases of complications and, by the 1930 s, medical aid was called in about one in every four cases. ${ }^{51}$ But the difficulty might have been overcome by the time the doctor arrived, or the midwife might have continued under his direction.

The law about unlicensed attendance was not always observed. Acknowledging a residue of illegal midwifery, the Midwives Committee reported in 1929 that further repressive legislation would be ineffective and that only a national midwifery service would eliminate it completely. 52

The independent practice that, until 1936, was the basis of home midwifery could be supported and supplemented by local authorities, aided by grants from central government, ${ }^{53}$ but public funding could secure an adequate national service only to the extent that local powers were exploited. Any subsidies were for midwives, not mothers; any aid for the necessitous was in services, not cash. The maternity benefit available through National Insurance to women covered by their own or their husbands' contributions was meant to help with the general expenses of childbirth, not specifically with the costs of attendance, but it was sometimes invoked as a guide for setting fees. ${ }^{54}$ Resisting suggestions that it should be tied to midwifery, the Midwives Committee reported that, although the present need was for services, it saw no justification for changing the existing benefit and no reason to think it ill-used. ${ }^{55}$

The rule obliging midwives to call out doctors was not matched by a requirement for them to respond. Before 1919, when local authorities had to pay fees to doctors answering calls for medical aid, midwives sometimes guaranteed the fees themselves, possibly through collective funds. ${ }^{56}$ In Cambridgeshire, in 1913, doctors insisted that

\footnotetext{
49 Towler and Bramall, op. cit., note 18 above, p. 214.

${ }^{50}$ See note 45 above.

51 Ministry of Health, Interim Report, note 1 above, p. 93n.: in England, excluding Wales, 353,002 cases were attended by midwives in 1928 ; doctors were summoned in $25.3 \%$ of cases $(21.83 \%$ in London, $25.3 \%$ in County Boroughs, and $26 \%$ in County areas).

52 Ministry of Health, Report on midwives, note 7 above, para. 67 , p. 81 .

53 The Midwives Act (1936) established statutory services of salaried midwives.

54 Walker, op. cit., note 46 above, p. 339: maternity benefit as the base for midwives' fees of $15 s .0 d$., i.e., half the benefit, leaving half for the mother; Charmian Kerr, 'The politics of married working class women's health care in Britain, 1918-1939', M. Phil. thesis, University of Sussex, 1979, p. 23. The QI's Annual Report for 1912 refers to the benefits becoming payable in 1913, with associated expectations of increased fees.

55 PRO MH55/244: Midwives Committee drafts; a rejection of the proposal to attach conditions to State benefit, suggested as a means of eliminating unqualified midwifery. Dame Janet Campbell (DBE, Birthday Honours, 1924) and Mrs Bruce Richmond, of the QI, doubted the advisability of depriving mothers of a free hand in disposing of the money.

${ }^{56}$ Lewis, op. cit., note 2 above, p. 149; Walker, op. cit., note 46 above, p. 339: a scheme for a panel of midwives charging $15 \mathrm{~s} .0 \mathrm{~d}$., of which $1 \mathrm{s.0d}$. was put into a medical aid fund.
} 
the standard equipment carried by nursing associations' midwives must include a guinea to be handed over to the doctor who came on call, ensuring him of at least half his usual fee. ${ }^{57}$ Fees were contentious even after 1919: in 1935, the Ministry of Health received complaints about doctors who refused to take bookings from women referred to them during pregnancy by midwives acting in accordance with the rules governing their work. ${ }^{58}$ The complaints were backed by details of eleven examples from the previous three years, with seven maternal deaths and four women still at risk. Local authorities' payments to doctors were, in practice, only for emergency attendance and, after 1930 but starting at different times from place to place, for the routine antenatal examination of women who had booked a midwife. Fees were not guaranteed for antenatal medical care and pre-arranged medical attendance at confinements, although local authorities were empowered to pay them. ${ }^{59}$

\section{MIDWIVES AND THE MEDICAL PROFESSIONS}

After the Midwives Act of 1902 came into force, women styling themselves as midwives had to be enrolled by the Central Midwives Board (CMB), a statutory body which determined training requirements, conducted examinations, laid down rules of practice, and applied disciplinary sanctions. The CMB's provisions were enforced by local authorities and its qualification, introduced in 1905, superseded earlier ones recognized for midwives' initial enrolment, which included unqualified women who had been in "bona fide" practice for at least a year.

The CMB's rules were rigorous and specific; supervision was often oppressive. In 1928, midwives complained of humiliating visits to public disinfection stations enforced upon them before they could resume work after the statutory suspensions required on contact with infection; of health visitors checking up on them by questioning recently-confined mothers; of not being allowed to use such drugs as they had been trained to administer. ${ }^{60}$ The statutory recognition did not denote society's acceptance of the profession's capacity for self-regulation, but established an apparatus for protecting the public from two kinds of midwives, two groups of potentially dangerous women, outlawing one and policing the other.

The Midwives Committee conceded in 1929 that the rules governing midwives' practice were unnecessarily constraining. The "bona fides", likely to be older, married women not in full-time practice, were dying out and midwives could be described as younger, more likely to be single, and more professional than their predecessors. ${ }^{61}$

${ }^{57}$ PRO PRO30/63/25: QI papers for 1913 on Cambridgeshire County Nursing Association, which recommended district associations to charge $12 \mathrm{~s} .6 \mathrm{~d}$. per confinement, $2 \mathrm{~s} .0 \mathrm{~d}$. per case to be pooled to provide the guineas, as was said to be the practice in Cambridge (presumably by the town's independent midwives).

58 PRO MH55/759, QI's deputation to Ministry of Health, March 1935.

59 PRO MH55/242, regarding Mrs Bruce Richmond's comments on working paper no. 5, draft report of Midwives Committee: the existence of the provision was not generally known or, at least, not much used.

60 PRO MH55/239, personal submissions to Midwives Committee from, e.g., midwives, the matron of a maternity home, a superintendent of district nurses; QI's submission of list of local restrictions on use of drugs.

6 Robert Dingwall, Anne-Marie Rafferty, and Charles Webster, An introduction to the social history of nursing, London, Routledge, 1988, p. 162, citing Lewis, op. cit., note 2 above, pp. 144-5 and Oakley, op. cit., note 2 above, pp. 108-9. 


\section{Maternal welfare in England and Wales}

But this merely meant a short training period: three months to begin with, six from 1916 and twelve from 1926, less for trained nurses. As midwives trained in the 1920s were less likely to take up independent practice, which was popular for married part-timers, how much real difference in social characteristics and standards of practice there was between the domiciliary midwives of the early 1900 s and those of the early 1930 s is debatable. Midwifery was uncharted territory in 1902, when estimates of the numbers of practising midwives, varying from 9,000 to 15,000 , were confounded by the CMB's initial enrolment of 22,308, of whom 9,787 had qualifications. $^{62}$

It is difficult to know what to make of the "bona fide" midwives' reputed inadequacies. Accounts of an illiteracy rate of 37 per cent in Yorkshire midwives in 1905, and of insanitary practice there and in Cumberland in 1911, were typical; anecdotes about midwives' inability to use thermometers have been retailed to the point of tedium. ${ }^{63}$ The "bona fides" of the early 1900 s were often described as unteachable on evidence that, unsurprisingly, shows them to have been unlettered. It might well be compared to the resistance, in 1908, to proposals for including a simple written examination in the major district nursing organization's scheme for training nurses in district work, on the grounds that it would discriminate against some candidates. ${ }^{64}$ All had to be hospital-trained to the best standards of the day before being accepted for the further training.

The worst "bona fides" were never said to be representative, but evidence has sometimes been misleadingly presented. For example, "In 1908, seventy-three per cent of midwives still practised without antiseptics and twelve per cent conformed to the drunken stereotype of Sarah Gamp" might be read as for all midwives. ${ }^{65}$ The statistics are from a report of the Medical Officer of Health for Hull, cited by Lewis, who has noted that many "bona fides" were skilled practitioners and that the CMB's rules protected against dangerous practice. ${ }^{66}$

Official inspection was supposed to provide some guarantee of midwifery standards and, whether or not these were better than before, J. S. Fairbairn's paper of 1927 provides some insight into them. ${ }^{67}$ Covering the period from 1905 to 1925 , it was based on the midwifery records of district nursing associations co-ordinated by the Queen's Institute of District Nursing.

Fairbairn compared the maternal mortality rates recorded for women in the care of the nursing associations' midwives with the national rates for 1905-1925. After correcting for the differences between the associations' recording practices and civil registration, he concluded that their maternal mortality rates were about half the

\footnotetext{
62 Dingwall et al., op. cit., note 61 above, pp. 158-9.

${ }^{63}$ Loudon, 'Deaths in childbed', note 2 above, p. 39; Dingwall et al., op. cit., note 61 above, p. 159; Betty Cowell and David Wainwright, Behind the blue door, London, Baillière Tindall, 1981, pp. 43-4; Jean Donnison, Midwives and medical men, rev. ed., 1988, London, Historical Publications, p. 179; Lewis, op. cit., note 2 above, p. 143.

${ }^{64}$ PRO PRO30/63/222, QI's papers on Liverpool Queen Victoria District Nursing Association: notes of conference on theoretical instruction, 20 March 1908.

${ }^{65}$ Loudon, 'Deaths in childbed', note 2 above, p. 39.

66 Lewis, op. cit., note 2 above, pp. 143-4.

${ }^{67}$ Fairbairn, op. cit., note 21 above.
} 
national ones, with similar fluctuations. He observed, also, that London's East End Lying-in Home, with a district as well as a hospital practice, had an even better record than the nurse-midwives' -0.67 per 1,000 deliveries over the previous four years - but he did not adjust it for precise comparison. The Home's medical aid was from a particularly experienced local practitioner; its rate of forceps delivery was 2.38 per cent, materially less than the nurse-midwives' rate of over 6 per cent in the mid1920 s. $^{68}$

The nurse-midwives' rates of calls for medical aid had risen from 8.9 per cent in 1905 to 26 per cent in 1925 . These included calls in pregnancy, in the puerperium, and on behalf of the baby but, in 1924 and 1925, about two-thirds were for difficulties and delays in labour and about half of these led to forceps deliveries. Nurse-midwives were scattered in rural districts all over the country and their medical aid came from local general practitioners.

In 1933, the obstetrician J. M. Munro Kerr prescribed a service of employed midwives; it was doubtful whether the Midwives Committee's recommendations for supporting independent midwives had ever been realistic. ${ }^{69}$ Whilst dissenting from the majority opinion in the British College of Obstetricians and Gynaecologists that midwives should hold nursing qualifications, both Kerr and Fairbairn were disappointed by the rates of calls for aid: 30.7 per cent for the nurse-midwives in 1931. ${ }^{70}$ Fairbairn reckoned that midwives then in practice were less confident than their predecessors but Kerr disagreed, and emphasized that, "Probably it is due more to the demands for anaesthetics and operative interference by the patients and relatives". ${ }^{71}$ Estimating forceps delivery to be necessary in no more than six to eight per cent of cases and comparing rates of 2.5 per cent at London's East End and York Road lying-in hospitals with the nurse-midwives' rates of 6.85 per cent in 1931 he wrote: "The higher rate in the latter service is due to the fact that the midwives are compelled by the patient or relatives to summon the doctor (in many cases unnecessarily) to terminate the labour" ${ }^{72}$ Shorter has repeated this uncritically, referring to the nurse-midwives' rate as more than twice that of several big London hospitals. ${ }^{73}$ This is to disregard not only the totally different circumstances of the two types of practice, but also Kerr's description of the East End and York Road hospitals, which he characterized as small, and staffed by midwives in supervised training.

By 1933, the official reports had opened to wider discussion the shortcomings of midwifery in medical training and general practice that had long been of concern to

\footnotetext{
${ }^{68}$ Shorter, op. cit., note 4 above, pp. 153 and 344 (n.91), citing Henry Jellett, Causes and prevention of maternal mortality, London, 1929.

69 J. M. Munro Kerr, Maternal mortality and morbidity, Edinburgh, E. \& S. Livingstone, 1933, ch. 14, especially p. 304; PRO MH55/246, memoranda on costings, and the administrative and financial complexities of proposals to link maternity services and maternity benefits; complications to do with women covered for medical services by national health insurance.

${ }^{70} \mathrm{Kerr}$, op. cit., note 69 above, ch. 10, p. 247, and p. 311: BCOG's recommendations to the Ministry of Health.

71 Ibid., p. 247.

72 Ibid., pp. 113-14.

${ }^{73}$ Shorter, op. cit., note 4 above, pp. 155-6, but he cites the nurse-midwives' rate for 1926 as atypically low for "the Anglo-Saxon world" (p. 153).
} 


\section{Maternal welfare in England and Wales}

obstetricians, but the principle of midwives' deference to general practitioners as authoritative birth attendants was not directly questioned. ${ }^{74}$ The obstetricians' remedy was for all cases at risk to be identified and referred for treatment and hospital confinement as necessary. As he counted all primagravidae and women with histories of difficulty in childbirth as at risk, Kerr's prescription for systematic, antenatal monitoring by midwives (for whom he recommended longer training, to include antenatal care) amounted to an exercise in limiting the potential damage by general practitioners.

The calls for medical aid bear closer examination. Fees were not guaranteed when midwives were first required to call for aid; local authorities' supervision took some years to become regularized; the enforcement of the CMB's rules was tightened up in the 1920s, entailing more precautionary calls. ${ }^{75}$ Although Kerr and Fairbairn both held the securing of natural delivery to be the criterion of good midwifery, midwives' training stressed the importance of recognizing signs of potential difficulty, and high rates of calls for aid were interpreted in some quarters as evidence of alert midwifery and good quality of care. ${ }^{76}$

The nurse-midwives' call-out rate of 26 per cent for 1925 (little different from that for all midwives) is not remarkable in the changing administrative context. If it may be assumed that the calls for reasons other than delays or difficulties in labour were uncontentious, and that the ones which ended in forceps deliveries were justified even if the interventions were not, then the nurse-midwives erred on the side of caution in no more than one in three calls. In 1933, Kerr remarked on the continued increase in calls for aid without speculating whether publicity about maternal mortality might have influenced mothers' and midwives' behaviour. Neither he nor Fairbairn, who had noted that more precautionary calls were being encouraged, mentioned that medical aid need not have led to medical intervention, or cited evidence that doctors complained of needless calls.

The story of importunate clients is as open to question as that of irresolute midwives. Kerr attributed the rising incidence of institutional confinements-about one in every four when his work was published - partly to some women's fear of complications and it is also likely that others who wanted to be sure of having their home confinements eased by aids not available to midwives would book doctors. Shorter has cited Flora Thompson's memories of village women's stoicism in childbirth as part of an outdated Victorian culture, but the stigma said to have been attached to accepting anaesthesia in a London lying-in hospital, and the recollections of women who had babies in the 1920s and 1930s, suggest that medical intervention and relief from pain continued to carry some sense of maternal failure. ${ }^{77}$ An informant's story of her uncomplicated birth's having been "the talk of the street" in

\footnotetext{
${ }^{74}$ Campbell, Maternal mortality, note 1 above, pp. 39-40, 75; Ministry of Health, Interim (p. 37), and Final (para. 174, pp. 94-5) Reports on maternal mortality, note 1 above; Report on an Investigation, note 1 above, pp. 281-5; Lewis, op. cit., note 2 above, p. 148.

${ }_{75}^{75}$ Fairbairn, op. cit., note 21 above, p. 48; Walker, op. cit., note 46 above, p. 337.

${ }^{76}$ Lewis, op. cit., note 2 above, pp. 148-9.

77 Ibid., pp. 130; Elizabeth Roberts, $A$ woman's place, Oxford, Blackwell, 1984, p. 108; Shorter, op. cit., note 4 above, pp. 146, 343n.
} 


\section{Enid Fox}

Slough, as late as 1943 , because it was attended both by doctor and midwife bears out the point: her mother's telling of it always included the defensive explanation that the family doctor, passing by and remembering her advanced pregnancy, made an informal call and found the birth imminent. ${ }^{78}$ And the horrors of failed interventions could not have been medical secrets. ${ }^{79}$ As Kerr observed of the Queen's Institute's warning, that its data on cases where nurse-midwives acted as maternity nurses were not from first-hand reports and so should be treated with reserve, "the nurse always knows whether the mother lived or died" ${ }^{80}$ So did her family and friends.

But mothers, families, and midwives were all viewed as scapegoats, despite the nurse-midwives' low maternal mortality rates. The comparisons of nurse-midwives' work with that of London lying-in hospitals implied that women with more confident midwives and less insistent friends would have suffered less from the unwise interventions which, it seems to have been assumed, doctors made on demanddespite the superior medical knowledge that was their rationale for being there at all. Perhaps because of doubts about general practitioners' capacity for antenatal work, neither Kerr nor Fairbairn raised the possibility that guaranteed fees for antenatal treatment might have shifted some calls for aid from the "labour" to the "pregnancy" category and resulted in more prearranged admissions to hospital. General practitioners' inadequate training and inexperience were certainly implicated, but outright censure was rare. More typical are references to the disadvantageous circumstances that doctors might contend with in domestic confinements; Mabel Dobbin Crawford's study of 100 "failed forceps" cases in Liverpool is exceptional for its strong and explicit criticism of general practitioners and their training. ${ }^{81}$ Andrew Topping is on record as saying that many maternal deaths were nothing short of murder, but the published note of the meeting of Medical Officers of Health which he addressed gives no details of the "glaring examples" which he described in discussion. $^{82}$

The Midwives Committee's comments on medical students' midwifery training, which follow its findings on the state of the midwifery profession, give pause for thought. The Committee found that there were too many independent midwives to be maintained in full-time practice, but they were crowded in the towns and often working part-time. "Little-practice" or "pin-money" midwives were thought to depress the general level of fees and likely to give a poorer service than full-timers. Rural areas were served by district nursing associations or not at all. There was ample evidence of independent midwifery's limitations as a career: low earnings, day and night commitment in all weathers, early incapacity, no provision for old age, oppressive supervision, the anxieties of private practice.

\footnotetext{
${ }^{78}$ Personal communication, P. R. Kent, Hatfield Polytechnic, February 1988.

79 PRO MH55/681, 'Brief statement of conclusions', (confidential report to the BMA, 1937); Shorter, op. cit., note 4 above, pp. 153-4; Mabel Dobbin Crawford, 'The obstetric forceps and its use', Lancet, 1932, i: 1239-43.

${ }^{80}$ Kerr, op. cit., note 69 above, p. 252.

${ }^{81}$ Ministry of Health, Report on an Investigation, note 1 above, was possibly the most critical of the official reports. Crawford, op. cit., note 79 above, found no reason for the use of forceps in 20 cases, contra-indications in 52, and the required conditions present at the time of application in only 4.

82 Topping, op. cit., note 5 above, p. 349.
} 


\section{Maternal welfare in England and Wales}

Most candidates for training did not become practitioners. ${ }^{83}$ Only 14,479 of the 56,670 midwives on the CMB's roll in 1927 notified an intention to practise. Candidates were often qualified nurses wanting a midwifery certificate so as to follow an occupation requiring the double qualification or to enhance their career prospects. Of 2,811 candidates in $1928,1,730$ had nursing qualifications and the rest were expected to take up salaried employment rather than independent practice.

The Midwives Committee referred disapprovingly to nurses who sought a midwifery certificate as "an ornament" to their professional qualifications. In acquiring it for so frivolous a reason they monopolized the "beds" or "clinical material" (parturient women) that medical students needed for a proper training in midwifery. The Committee's language, like Eardley Holland's in his history of midwifery in medical education, presented the matter as if it were within the pupil midwives' control. "These women absorb a considerable amount of the training material to the detriment of the interests of medical students in schools which are sometimes hard pressed to obtain adequate facilities ... students in a medical school ... should have preference in the apportionment of material . . . If pupil midwives . . . are not able to obtain a sufficient number of cases to qualify for entrance to the examination of the Central Midwives Board they should go elsewhere..."; "The pupil[ midwive]s came first and the [medical] students' share was as a rule only a small and totally inadequate one". ${ }^{84}$ Not only were midwives at fault if women in their care fell victims to medical accidents at the hands of doctors called out under the CMB's rules, they were also to blame for such doctors' inadequate training.

Nothing was said about how a midwifery certificate unsupported by post-qualifying experience had come to be a passport to lucrative posts, nor what determined the allocation of beds so that the pupil midwives had such a great advantage in the teaching hospitals where the shortage was most acute. According to Holland, the medical curriculum was already too full at the turn of the century to allow for more midwifery. Anecdotes abound on the subject of its casual treatment well into the $1920 \mathrm{~s}^{85}$ Topping was candid about his lack of experience before he took charge of several antenatal clinics, despite the "somewhat perfunctory" course in antenatal work included in his studies for the Diploma in Public Health: "By dint of native guile I did my best to conceal my ignorance ... [ [which was] shared by many medical men in the district". 86

In 1922, the General Medical Council recommended a course of instruction with six months' clinical training. That the prescription was not fully implemented was put down to the scarcity of beds rather than infirmity of educators' purpose. The value of pupil midwives' labour to the institutions where they trained, and any part it may have played in what Holland called "the Battle of the Beds" were never mentioned. He does not record when the battle might have been deemed over, although all training needs were met by the early 1950 s. $^{87}$ The critical question of midwives'

\footnotetext{
${ }^{83}$ Ministry of Health, Report on midwives, note 7 above, para. 3, p. 22.

${ }^{84}$ Eardley Holland, 'The medical schools and the teaching of midwifery', ch. 30 in Kerr et al. (eds.), op. cit., note 46 above, p. 302; Ministry of Health, Report on midwives, op. cit., note 7 above, para. 35, p. 24.

${ }^{85}$ Holland, op. cit., note 84 above, p. 301; Oakley, op. cit., note 2 above, p. 111; Lewis, op. cit., note 2 above, pp. 146-8; Geoffrey Barber, Country doctor, Ipswich, Boydell Press, 1973, p. 77.

86 Topping, op. cit., note 5 above, p. 343 .

${ }^{87}$ Holland, op. cit., note 84 above, p. 302.
} 
supply, left unresolved as the Midwives Committee's recommendations came to naught, was settled by the Midwives Act of 1936, which nationalized midwifery.

\section{THE MIDWIVES ACT OF 1936}

In effect, the Act implemented the recommendations of the independent Joint Council on Midwifery, set up in 1934 at the instance of the National Birthday Trust and representing Medical Officers of Health, general practitioners, midwives, obstetricians, and gynaecologists. Given the disarray in the midwifery profession, the new Midwives Bill was uncontroversial, even though the British Medical Association complained that the Joint Council's report was released before its members had time to consult their parent bodies. ${ }^{88}$ But its objections were too insubstantial to delay the legislation.

The Act required local authorities to provide enough full-time, salaried midwives to meet all needs, either by direct employment or through voluntary agency. The principal innovation (for local authorities were already empowered to support and employ midwives) was for the retirement and compensation of independent midwives who were not to be employed in the new service or to continue in private practice, an uncertain prospect with competition from the public sector.

The other provision both major and new was the prohibition of unqualified maternity nursing, directed at the "handywomen" whose attendance was believed to extend to conducting deliveries with doctors' collusion. It meant loss of livelihood for some women whose maternity nursing was not a cover for illegal midwifery, but it was easier to prohibit their activity than to enforce sanctions against conniving doctors; the Ministry of Health's advice had always been that any maternity nursing provided by local authorities under the permissive powers of the Maternal and Child Welfare Act of 1918 should be by women with midwifery qualifications.

The BMA, possibly aware that recommendations unfavourable to its members might emerge from research then reaching completion, expressed concern that a service centred on local authorities might exclude general practitioners, but it had no grounds for resisting a proposal aligned with long-standing policies for developing local authorities' maternity and child welfare services. ${ }^{89}$ Local authorities set charges for midwifery and were empowered to recover them. They tended to be at the upper end of the range quoted for nursing associations at the end of the $1920 \mathrm{~s}: £ 2$ or more for a first birth. The Ministry of Health estimated that fees averaging $£ 1.5 s .0 d$. per case would be recovered at the outset, with the authorities sustaining net costs of $£ 170-180$ per annum for each midwife employed; midwives' pay compared reasonably with health visitors' and was a considerable advance on the independent midwife's expectations of net earnings. ${ }^{90}$ The Midwives Committee's recommendations had been

\footnotetext{
${ }^{88}$ PRO MH80/13, representations on the Midwives Bill, 1936; correspondence with the BMA, January 1936.

89 Ibid.

90 PRO MH55/239, QI's evidence to Midwives Committee; MH55/660, estimates of the costs of salaried service; PRO30/63/68, 111, 436B, examples from QI's papers on County Nursing Associations: Derbyshire, certificated midwives $£ 175$, SRNs $£ 200$; Essex, $£ 170$ and $£ 190$; Warwickshire, $£ 180$ and $£ 200$; MH80/13, a list of health visitors' salaries as advertised in nursing journals.
} 


\section{Maternal welfare in England and Wales}

directed to securing the supply of midwives by enhancing their professional status; public employment now stood to have the desired effect through its pay and pensions, and career prospects within midwifery for nurses with midwifery qualifications. But the new policy meant the virtual disappearance of independent midwives.

Although the principle of women's free choice of medical attendant was affirmed in the planning of the Midwives Act of 1936, municipal midwifery has been said to have resulted in general practitioners' obstetrics being limited to a minority who became especially experienced. ${ }^{91}$ The explanation for this perception lies in the aftermath of a special investigation into maternal mortality that was nearing completion as the Act went through.

\section{OCCASIONAL CALAMITIES}

The investigation was into the causes of deaths in places with maternal mortality rates exceeding 5 per 1,000 live births for the period from 1924 to 1933; Halifax led the English league table with 7.05 and the rates for Wales were so high as to justify a separate inquiry. ${ }^{92}$ Official, professional, and popular publications combined, round about the time of the inquiries, to offer reassurances on the subject of death in childbirth, with the medical press "[supporting] the government's view that the problem was administrative and scientific, demanding specialist study rather than popular debate". ${ }^{93}$ Women's magazines in 1936 took different routes to reassurance, Home Notes by avoiding the topic as something sensible wives should not get "all hot and bothered" about; Woman's $O w n$ by a series of articles that included references to statistics' being misleading although "every now and then . . . a calamity occurred".94

In fact, the chief recommendation prompted by the investigation, but never published, was that some doctors should be barred from midwifery. At the end of 1936 Sir Arthur MacNalty and Sir Comyns Berkeley, both relatively new appointees to their offices as Chief Medical Officer of the Ministry of Health and Chairman of the CMB, respectively, on the retirements of Sir George Newman and John Shields Fairbairn, agreed with senior officials at the Ministry that some general practitioners were too inexperienced to practise midwifery. Under the CMB's rules, midwives calling for medical aid were bound to respect the mother's choice, but local authorities might want some control over the choice of doctors called by their salaried midwives and the London County Council had already raised the issue. The College of Obstetricians and Gynaecologists favoured restriction of choice; Sir Comyns Berkeley thought the BMA could be convinced and the CMB's rules changed. There was full agreement that the publication of particulars of individual cases was undesirable, for fear of alarming mothers. So a revised form of the report's conclusions was agreed for publication, and a confidential report put in hand for the BMA. $^{95}$

\footnotetext{
91 Walker, op. cit., note 46 above, p. 347.

92 Ministry of Health, Maternal Mortality in Wales, note 1 above.

${ }^{93}$ Lewis, op. cit., note 2 above, p. 40.

94 Ibid., pp. 40-1.

95 PRO MH55/681, minute of discussion, 16 December 1936. The published report was Ministry of Health, Report on an Investigation, note 1 above.
} 
It was a short, selective presentation. ${ }^{96}$ The full study covered 669 deaths, 101 deaths from abortion having been excluded. Private doctors were responsible for the supervision of 55.9 per cent of cases; most had been engaged for the confinement. There were 73 deaths from eclampsia, essentially preventable, and supervision had been careful in only 9 of the 43 eclampsia cases that were attended by doctors. Doctors had been responsible for the antenatal care of 24 of these cases; and midwives had made antenatal referrals in 6 others. Examples of unsatisfactory care included failures to test urine, to take blood pressure and to recognize the import of symptoms; table 2 analyses the 109 deaths from sepsis.

\section{Table 2: Deaths from sepsis}

Hospital confinements

Handywoman present, no doctor called

Midwife present, no doctor called

Doctor booked for confinement (including 16 with midwife as maternity nurse) 39

Midwives' cases, with medical aid

$\begin{array}{lr}\text {-delay and difficulty in labour } & 19 \\ \text {-breech presentation } & 5 \\ \text {-twins } & 1 \\ \text {-tranverse presentation } & 1 \\ \text { - ante-partum haemorrhage } & 2 \\ \text {-difficulty with placenta } & 3 \\ \text {-post-partum haemorrhage } & 1\end{array}$

Total

(Source: Ministry of Health, confidential report on maternal mortality investigations, 1937: 'Brief statement of conclusions'.)

Forceps were applied in 48 of the 71 home confinements with doctors present, with more than one application in 8 cases. Of these, 4 deliveries were accomplished at home and 4 in hospital by forceps, craniotomy, and Caesarean section. There were 8 cases of severe lacerations of the perineum, complete to the rectum in 5 cases and with additional tearing in 4, and evidence of lack of care or error of judgement in cases of haemorrhage.

Short accounts of a sample of 18 cases were provided, exemplifying unskilled midwifery (6 cases), inadequate antenatal supervision (5), errors of judgement (4) and late admission to hospital (3).

General practitioners had been booked for all but three of the confinements in the sample. One of these cases was classified as unskilled midwifery: delivery was in a local hospital, by Caesarean section, undertaken by a general practitioner after the woman had been attended by two others in a municipal maternity home. Another was a case of inadequate antenatal supervision by a doctor who, without detecting pregnancy, treated a patient for three weeks after which she was admitted to hospital suffering from vomiting and fits. She died, 28 weeks pregnant. The third was a late admission to hospital after a midwife called medical aid for a breech presentation. Death was from sepsis the day after manual delivery following an unsuccessful

\footnotetext{
${ }^{96}$ PRO MH55/681, 'Brief statement', note 79 above.
} 


\section{Maternal welfare in England and Wales}

attempt with forceps and five days after the start of labour; the woman was dying on admission to hospital.

The other 15 cases included detailed examples of forceps damage, one with extensive tearing of the vulva and vagina and a torn-off labium majus; there were extended, exhausting interventions preceding removals to hospitals, and a Caesarean section undertaken in a general hospital by a general practitioner who, although unskilled in obstetrics and surgery, refused the Medical Officer of Health's offer of a consultant to be paid for by the local authority. These were all classified as unskilled midwifery.

Doctors' inadequate antenatal supervision included failures to test urine and take blood-pressures, and errors of judgement included a ruptured ectopic pregnancy diagnosed as a gastric ulcer, mismanagement of haemorrhage, and a doctor's failure to ensure complete delivery or obtain a consultant's assistance before leaving the patient.

"Late admission to hospital" often meant delay until death was inevitable, and the best of hospital care would have been unavailing. The three sample cases included a woman who had been ill throughout her three-and-a-half months' pregnancy and bedridden for her last month of life. For a week, her family "begged" the doctor to send her to hospital, after which the Medical Officer from the local authority's Maternity and Child Welfare service arranged admission but, by then jaundiced and near-comatose, she died two days later.

The other cases were the woman who arrived at hospital dying of sepsis and one who died from shock after a difficult labour ended by Caesarean section. She had been under the antenatal care of the doctor who referred her to hospital after three days of labour, when the pelvic condition that caused her difficulties was first diagnosed.

The confidential report acknowledged that general practitioners were likely to be handicapped by unsuitable surroundings, inadequate assistance, pressure of other calls, and patients whose condition demanded immediate action; and that some case histories showed that careful obstetric procedures had been followed. Another, somewhat back-handed softening of the report's strictures on general practice was its observation that whilst many hospitals gave efficient treatment, some were not of a high standard, often with no obstetrician on the senior staff and where difficult confinements were conducted by juniors. Doctors' declining opportunity for becoming experienced in obstetrics was mentioned in connection with falling birth rates, more institutional confinements, and more attendance by midwives.

According to the researchers, some doctors could not get enough midwifery practice to become efficient. It was sometimes confined to medical aid cases, and doctors attending a few abnormal confinements a year could not bring to them the judgement and experience they required. Many of the deaths that were investigated might have been avoided by experienced practitioners, specialized obstetric assistance or earlier admission to hospital.

The discussions surrounding the confidential report concentrated on the CMB's rule that medical aid in midwives' cases should be by doctors of the patients' or their families' choice, even though the proportion of doctors' cases in the investigation was unrepresentatively high. Institutional and midwives' cases must have accounted for 
more than 80 per cent of all confinements, but nearly 55 per cent of the ones investigated were doctors' cases. There were 15 doctors' cases in the sample of 18 and a doctor implicated in one of the others. The BMA was first consulted in December 1936, with reference to 18 per cent as the proportion of all confinements entailing calls for medical aid, and was thought to be amenable to the calls being restricted to doctors trained or experienced in obstetrics. ${ }^{97}$ Later the BMA hardened its line and stood out for its own version of a maternity service that, the Ministry said, would cut across the system of over 1,600 antenatal clinics that had developed over the previous fifteen years, and agreed to local panels of practitioners available for midwifery only on condition that they would be self-selected. ${ }^{98}$ The Ministry recommended local authorities to set up committees to advise on standards of practice, ${ }^{99}$ and, more significantly, the CMB's rule about the choice of doctors for medical aid was rescinded.

Frank Honigsbaum's account of general practitioners' long resistance to tests of specialist competence and insistence that "all GPs are equal" suggests that the Ministry's initial assessment of the BMA's favourable attitude to midwifery panels was ill-founded. ${ }^{100}$ Few panels eventuated and local authorities tended to rely on the informal selection of preferred practitioners that was possible without the CMB's constraining rule. Arnold L. Walker, who followed Sir Comyns Berkeley as Chairman of the CMB, wrote in 1954 that, by the end of the 1930s, general practitioners' midwifery was, in effect, limited to experienced doctors. A "body of general-practitioner-obstetricians . . . has developed spontaneously". 101

By this account, then, there was no conflict, no administrative intervention, no demand management, no influence by way of the CMB's change of its rules: rather, the orderly evolution of an ever-improving service by way of rational consensus. But by the time the National Health Service was launched and more than half of all confinements were in hospitals, general practitioners attended very few in response to calls for aid; the 15 per cent or so which they accounted for were mostly by prior booking and not within local authorities' control. ${ }^{102}$ Members of the Royal College of Obstetricians and Gynaecologists still bemoaned lives lost at inexperienced hands and prophesied worse, failing changes in the National Health Service's midwifery provisions. What is to be made of all this?

\section{CONCLUSIONS}

Scientific medicine's success in bringing down the death-rates, obstetricians' persistence in seeking the application of life-saving techniques to the limits of current

\footnotetext{
${ }^{97}$ PRO MH55/681, note of conference with BMA representatives, 31 December 1936.

98 PRO MH55/682, A. J. MacLachlan, 27 July 1937: "a midwifery parcel for each area with every general practitioner entitled to put himself on it"; and 7 June 1937, noting the gist of a statement in the British Medical Journal of 8 May 1937.

${ }_{99}$ Ministry of Health Circular 1705, May 1938.

100 Honigsbaum, op. cit., note 43 above, pp. 154-5.

101 Walker, op. cit., note 46 above, p. 347.

102 Joint Committe of RCOG and Population Investigation Committee, op. cit., note 38 above, pp. 48-9, 54: for all confinements, approximately $54 \%$ institutional, $29 \%$ midwives', $15 \%$ doctors', $2 \%$ with doctors' medical aid (extrapolated).
} 
knowledge, and the Chief Medical Officer's pressure on local authorities to provide maternity services as extensive as funds would allow all represent professionalism at work in the best traditions of personal and public service. ${ }^{103}$

But were obstetricians' emphasis on the hospitalization which, by 1944, they advised for 70 per cent of all births, and Sir George Newman's direction of official interest to clinical causation entirely disinterested? ${ }^{104}$ To point out that the Ministry exploited the emotive issue of mothers' needless deaths to promote a particular kind of maternity service is not to question Newman's genuine, humanitarian concern; but his reluctance, and that of the professional team led by him, to address related issues is telling. Neither the shortcomings of the independent research nor the lack of direct correlation between variations within the death-rates and indicators of deprivation were sufficient reasons for ruling out nutrition as a factor to be studied. And there was enough evidence of maltreatment to have justified more detailed research on midwifery in general practice, with particular reference to maternal morbidity and disablement. There might have been some action on these fronts had maternal mortality been the "public scandal" which Loudon has described-"from the beginning of this century [there was] . . increasing anger ... [maternal mortality was] heatedly debated not only by the medical profession and governments, but also by the general public, through the medium of the daily press and women's magazines"-but it never was. ${ }^{105}$ There is no reason to dispute Lewis's account of the stages of the public debate, with the Ministry taking the initiative in publicizing the issue and successfully containing the embarassment of the rates' continued obduracy. ${ }^{106}$ "It is now some fifteen years since the public conscience began to be really disturbed", remarked the Registrar General's Chief Medical Statistician in 1949, and he discerned the beginning of the death-rates' decline a year or so later. ${ }^{107}$ The Ministry could not be blamed for the economic crisis that put paid to its projected maternity service; later, much could be made of the statistical impenetrability of the death-rates' internal variations; ${ }^{108}$ and the line taken by some women's magazines in the mid-1930s suggests some not unsophisticated management of the media. The real scandal was the professionals' collusion in concealing bad practice, and it was never made public.

Professionalism at its most self-interested is evidenced by the treatment of the confidential report to the BMA. General practitioners, obstetricians, and Medical Officers of Health were at odds about maternity services and their proper centre of control-consulting room, hospital, or clinic-and the alleged deficiency of midwifery in general practice was common currency in much of their debate and borne out by the official, published reports. But when it came to exposing what lay behind the official expressions like "faulty antenatal care" or "error of judgement" by describing cases in terms that women could relate to their own bodies, the

\footnotetext{
103 See Paul Wilding, Professional power and social welfare, London, Routledge \& Kegan Paul, 1982, pp. 12-13.

${ }^{104}$ RCOG, Report, note 35 above, pp. 24-7: recommendations on hospital provision.

105 Loudon, 'Puerperal fever', note 2 above, p. 485; and 'Maternal mortality', note 2 above, pp. 184-5.

106 Lewis, op. cit., note 2 above.

${ }_{107}$ Gilliatt, op. cit., note 14 above, p. 286: Dr Percy Stocks, in discussion.

108 Ministry of Health, Report on an Investigation, note 1 above: 'Special Statistical Studies', V, pp. 60-111; Macfarlane and Mugford, op. cit., note 16 above, pp. 203-7.
} 


\section{Enid Fox}

professional men hung together. The one obstetrical contribution to the maternal mortality debate, five years earlier, which criticized doctors in plain terms and notably linked technical exposition to women's experience, was Mabel Dobbin Crawford's. ${ }^{109}$ When Andrew Topping criticized consultants for not telling what they knew, it is unlikely that he had in mind the open publication of details of such events as he described as "nothing short of murder"; he argued for simple, straightforward public education about pregnancy and childbirth. ${ }^{110}$

No doubt Sir Comyns Berkeley and Sir Arthur MacNalty were sincere in their concern for women's peace of mind, and the BMA's firm stance on self-selection may well have been part of a public-relations strategy that covered its agreement to the changes in the CMB's rule about calls for medical aid, but they left some women unnecessarily exposed to bad practice. The "sensible wife" who bought the staider women's magazines might reasonably have supposed that a doctor's higher fees meant better care than a midwife's; although her chances of death from a bad choice may have been only slightly increased, she may have been putting her future health at significantly greater hazard. Nineteen of the 88 survivors in Mrs Dobbin Crawford's study of 100 "failed forceps" cases were classified as "morbid"; Honigsbaum has cited a contemporary opinion that specialists' doctrines about the inadvisability of forceps in the 1930s did not deter general practitioners. ${ }^{11}$

The medical knights offered no protection to the woman who booked a doctor for a home confinement, and childbirth remained safer for poor East Enders than for women in well-heeled Hampstead. A recent statistical reconsideration, necessarily inconclusive in default of data whereby to test the hypothesis, suggests that the inverse association between maternal mortality rates and indicators of deprivation in London boroughs, and maternal death-rate tabulations related to social class in the Registrar-General's Decennial Supplement for 1930-1932 may reflect the fact that the effects of poverty were less dangerous than risky medical intervention with the better-off. ${ }^{112}$ There was a persuasive case for restricting the publication of material which might be turned to sensational effect, but Topping's account of women as eager for information and well able to assimilate it suggests that concealing the descriptive content of the special investigations' findings rather than seeking their unsensational dissemination, which could have led women to safer choices and strengthened the Ministry's hand on the question of midwifery panels, was vastly more culpable than chancing disproportionate public alarm.

Maternal mortality's rise and fall as a defined social problem may be read in terms of medical self-protection and control not only by reference to medical care itself, but also to interprofessional relationships. A full analysis of the implications for the midwifery profession is not possible here, but this paper does demonstrate the illogic of blaming midwives for doctors' actions and the inconsistency of the standards

${ }^{109}$ Crawford, op. cit., note 79 above.

110 Topping, op. cit., note 5 above, pp. 344-5.

111 Honigsbaum, op. cit., note 12 above, p. 11.

112 Macfarlane and Mugford, op. cit., note 16 above, p. 203: maternal mortality rates were higher in the East End than in Hampstead in the period 1924-1933 (that covered by the investigation of 1937); Macfarlane and Cole, op. cit., note 2 above, pp. 41-2: on the possibility of competing tendencies. 
applied to midwives' practice, even by those who asserted its value. Fairbairn noted the increased expectation of precautionary calls for medical aid; Kerr's prescriptions for routine hospitalization would have removed far more cases from home than were referred to doctors; yet they both deplored the increasing incidence of medical aid.

Professor Blair Bell, whose eminence has been noted in the first part of this paper, was no friend to "the present class" of midwife. In 1931, when he advocated a differently trained, hospital-based practitioner, he had to counter arguments that cited domiciliary midwives' good records in Britain and in Scandinavian countries with similar training systems. ${ }^{113} \mathrm{He}$ said that about 30 per cent of Swedish confinements were in hospitals, against six to eight per cent in Britain, and that the credit given to English and Welsh midwives did not allow for the aid they called for in about 25 per cent of their cases, with many not knowing enough to call for it in time. The rate for hospitalized confinements in England and Wales was approaching 24 per cent; Fairbairn's statistics included "medical aid cases" as midwives'; Bell offered no evidence for deviating from his fellow obstetricians' judgements that midwives called for aid too early and too often. The obstetricians' modes of argument, from Kerr's elision of inference and evidence about impatient families, through the variously partisan interpretations of calls for medical aid, to Bell's dubious use of statistics suggest that, when professional interests were at issue, ratiocination fell short of the standards expected of medico-scientific research.

Midwives had little influence over the Midwives Act of 1936, drafted when concern about the maternal mortality rates was at its highest and a remarkably radical reform was acceptable to the public. Financially, midwives did well out of it, but it reconstructed their occupational identity in ways which, indirectly and in combination with the increasing trend towards institutional confinement, produced a practitioner who had more in common with Blair Bell's ideal of a nurse with additional midwifery training than with the single-qualified women whose work comes out so well in Fairbairn's analysis. Questions remain about whether the outcomes of decisions taken in the 1930s, both in the shorter and the longer term, were in the best interests either of midwives or mothers, and the extent to which their undoubted favouring of the medical profession was in the public interest.

Obstetricians even now stand accused of misrepresenting statistics to support hospitalized childbirth; midwives are said to be torn between their employers' expectations and their responsibilities to women whose choices of confinement arrangements are against local policies; ${ }^{114}$ campaigns are mounted for rescuing home birth as a realistic choice in a society whose babies are nearly all born in hospitals. ${ }^{115}$

${ }^{113}$ Bell, op. cit., note 17 above.

114 Marjorie Tew, 'Birthplace: facts for fantasies', New Generation, December 1988, 7(4): 5-6: a survey carried out in 1984 by the NBT and the RCOG misleadingly represents birth as safest in a large "consultant" hospital. "This is what obstetricians believe and what they would like everyone else to believe. They have, however, no evidence whatsoever to justify their claim." See also Ishbel Kargar, 'Place of birth', Nursing Times, 16 November 1988, pp. 59-60: the idea of choice in patterns of care is gaining credence but the number of choices is shrinking.

115 Molly Lobban, 'Home birth, first international conference [October 1987]', in Midwifery, March 1988, 4(1): “A worldwide movement towards a 'rebirth' of midwifery emerged, with planned home birth a legitimate choice"; Rona Campbell and Alison Macfarlane, Where to be born?, Oxford, National Perinatal Epidemiology Unit, Radcliffe Infirmary, 1987, p. 12: 99 per cent of all births in 1985 were in hospitals. 


\section{Enid Fox}

Detached observers adduce evidence of demand for hospitalization, the different constructions that may be put on it, and the weaknesses in statistics-based arguments on both sides. ${ }^{116}$ It is worth noting that the obstetricians' bitter disappointment at the National Health Service's midwifery provisions was short-lived. Their recommendation of hospital beds for 70 per cent of births became official policy in 1959 , when the proportion already exceeded 60 per cent; it was fulfilled by $1965 .{ }^{117}$

The incidence of maternal mortality in this country is now too low to be any kind of index, ${ }^{118}$ but maternity services conditioned by it are the focus of today's impassioned debates, and reviewing past experiences may help in present troubles. A recent and careful consideration has drawn attention to the way in which policy on maternity care has been formed with very little reference to evidence; ${ }^{119}$ that such conclusions are not unusual in policy analysis is all the more reason for investigating the particular, circumstantial factors that have carried the day.

116 Campbell and Macfarlane, op. cit., note 115 above, especially pp. 57-9; Dingwall et al., op. cit., note 61 above, p. 172.

117 Macfarlane and Mugford, op. cit., note 16 above, (tables volume), pp. 237-8, Table A7.29: hospital births as a percentage of all births exceeded $70 \%$ in $1965,80 \%$ in 1968 , and $98 \%$ in 1978 .

${ }_{1}^{118}$ Campbell and Macfarlane, op. cit., note 115 above, p. 24; Erica Royston and Alan D. Lopez, 'On assessment of maternal mortality', World Health Statistics, Vol.40(3), Geneva, 1987, p. 214: at least half a million women die from maternal causes, but over 99 per cent, all but about 6,000, are in developing countries.

${ }^{119}$ Campbell and Macfarlane, op. cit., note 115 above, p. 59. 